\title{
The Development of Innovative Learning Module on the Teaching of Acid-Base Titration Based on Curriculum 2013
}

\author{
Debby Suci Martalina \\ Postgraduate School \\ State University of Medan \\ Medan, Indonesia \\ debbysuci@gmail.com
}

\author{
Yasir Arafat Hutapea \\ Department of Chemistry \\ University of Sumatera Utara \\ Medan, Indonesia \\ Arafatyasir195@gmail.com
}

\begin{abstract}
This research was aimed to develop innovative learning module on the teaching of acid-base titration based on curriculum 2013. It is essential to develop the standard and good module based on curriculum to address the requirement on student's competence in curriculum 2013. The description analysis of each textbook was based on content, extension, depth, design, and language. The result of description analysis books were categorized as a good textbooks; book $1(65 \%)$, book $3(50 \%)$, and book $4(65 \%)$. While, the textbook categorized as very bad textbook was book $1(35 \%)$. Based on that result, the module was developed and designed through laboratory experiment, outside activity, and learning media. The standarization of module was conducted by chemistry lectures of FMIPA UNIMED, chemistry teachers and students from MAN (Madrasah Aliyah Negeri) 2 Model Medan, MAN 1 Medan, SMA (Sekolah Menegah Atas) 5 Binjai. The average result obtained for the lecturer was 3.58 , the teacher was 3.92 , and students were 3.59 and the total average is 3.70. It was categorized as valid and the module was not needed to be revised anymore. It can be concluded that the module has successfully developed by the researcher, and obtained the standard module, and reasonable as learning media for students.
\end{abstract}

Keywods-innovative learning module; acid-base titration, curriculum 2013,

\section{INTRODUCTION}

The development of innovative learning module on the teaching of acid-base titration based on curriculum 2013 is very important as it is known that innovation in education is seen as the central concept for obtaining significant development in education. The innovations in education could be in a new practice in technology of teaching, aided instruction, teaching and learning activities, learning material, and another practice that bring improvement in education sector [1].

Textbook or learning module is a media that contains descriptions of educational materials about the subjects, compiled systematically and have been selected based on specific objectives, learning orientation, and development of students. With textbooks, learning programs can be implemented more regularly, because teachers as implementer of education will get clear guidance material. Module is a teaching material that contains a complete unit of learning subject, that is arranged independently with another subject, and the materials are arranged systematically in order to be used to help students in reaching the objectives that has formulated specifically and clearly. The learning module is consisted of concept and theory, illustration, drills, problems and answers. The learning module has to be able to help students to study by their style independently, so they use different technique to solve certain problems based on their knowledge background and their ability [2].

The development of chemistry learning module and textbook from Senior High School (SMA) and Madrasah Aliyah (MA) are important to get the quality of learning module and textbook of chemistry that can be used by students appropriate to curriculum 2013. The good and standard chemistry learning module can help the students to meet their competence in chemistry.

A good chemistry teaching module can help students to understand the concept of chemistry clearly. It is very important to use teaching and learning module in the teaching of chemistry subjects. The chemistry subjects that are developed are mainly categorized as difficult subject to be thought to students. Chemistry topic is dealing with investigation and calculation, where to understand chemistry concept the students need the knowledge as the combine of theory, practice and illustration [3].

In this research, researcher is interested to develop learning module of acid-base titration through integration of laboratory activity, outside activity, and learning media. Curriculum 2013 need to be implemented starting 2013, and therefore the study is processed on the development of chemistry module to meet the requirement to achieve student's competence. 


\section{METHOD}

The research was about the development of innovative learning module that was designed through integration of laboratory activity, outside activity, and learning media to get standard innovative learning module that can be used to help students in learning chemistry. The research was conducted through several steps. The research procedure consist of preparation of research studies, conducting research, data collection and analysis of research data $[4,5,6]$.

\section{A. Analysis of High School Chemistry Textbook}

The analysis and evaluation of chemistry textbook was aimed to investigate the content of chemistry textbook or module with acid-base titration topic, the suitability of the extension, the suitability of the depth and design, and bad or good the chemistry textbook have appropriated with the basic competence based on curriculum 2013.

\section{B. The Development of Innovative Learning Module}

Developing learning material by seeing basic competence based on curriculum 2013, where it has to be known that the main objective want to achieve with the acid-base titration topic based on curriculum 2013. The basic competences in curriculum 2013 are including; integration of laboratory experiment, integration of outside activity, developing teaching media, developing instrumentation (questionnaire, and evaluation test). standarization of innovative learning module.

\section{Standarization of Innovative Learning Module}

The innovative learning module must be standarized before the module was used in research because it must be appropriated with curriculum 2013 that contain the content, the extension, the depth, design, and language. And the module will be standarized by expert lecturer firstly, after that Chemistry teacher in target school; they will assess the standarization of module approprite to the questionnaire.

Evaluation of module was performed to students, where the students were given the same questionnaire to assess the standarization of innovative learning module, the learning module aim to help students easier to study chemistry with the certain topic of chemistry such as acid-base titration.

\section{Descriptive Analysis}

The descriptive analysis used for standardization of developed learning material in this research before the learning material was ready to be used by students in selected school. The learning material was assessed by expert judgment and the result that obtained was qualitative data. The data obtained was analyzed by using descriptive analysis of the percentage. This analysis was used for giving the percentage of assessment component of chemistry textbook content based on BSNP standard. The formula is shown below.

$$
P \%=\frac{(\Sigma q)}{(\Sigma r)} x 100 \%
$$

Note: $\mathrm{P} \%=$ Percentage of obtained score

$\Sigma q=$ Concept number with a sign $(\sqrt{ })$ the chemistry textbook of grade XI semester 2

$\Sigma r=$ Total number of existing concepts in chemistry textbook of grade XI semester 2

Average percentage result category; if percentage < $40 \%$ means very bad; $40 \%$ to $75 \%$ means good; $>75 \%$ means very good.

\section{RESULT}

\section{A. Survey of High School Bilingual Chemistry Textbook}

The researcher conducted a survey to the bilingual chemistry textbook which frequently used by students in grade XI IPA as handbook and available in bookstore. They were Esis, Yrama Widya, Bumi Aksara, and Grafindo. Researcher analyzed textbooks by the description criteria like contents, extention, depth, design, and language of the textbooks.

Based on the result of survey, the researcher performed analysis basic competence that appropriate to syllabus of Senior High School (SHS) grade XI semester 2 and determine the discussion topic that relevant to SHS/MA based on curriculum 2013. But the chemistry textbook grade XI based on curriculum 2013 is just found in one school and both of target schools are still using chemistry textbook based on KTSP. Textbook that is based on curriculum 2013 has an almost complete subchapter, same with one of the textbook that is based on KTSP (B4). To make a complete subchapter in module, researcher decided to combine both of subchapter that were contained in both of books to be a completed subchapter that were arranged as: (1) basic concept in acid-base titration, (2) indicator for acid-base titration, (3) calculation in acid-base titration, and (4) types of titration and its curve.

\section{B. Descriptive Analysis of High School Bilingual Chemistry Textbook}

Based on the survey result, there are four bilingual chemistry textbook that had been analyzed and given code as B1, B2, B3, and B4. The researcher analyzed the chemistry topic of Acid-Base Titration in grade XI at even semester for all target textbooks which appropriate with description criteria. The researcher assesed the textbooks by checking list $(\sqrt{ })$ in appropriate column of the questionnaire. After checking the questionnaire, the data that is gotten is calculated by the formula.

The description analysis of each textbook was based on content, extention, depth, design, and language. Based on the result of description analysis, the text books categorized as a good textbooks was B2 (65\%), B3 (50\%), and B4 $(65 \%)$. While, the textbook categorized as very bad textbook was B1 (35\%). It means that textbook code B2 was as good 
as B4. Textbook code B2 and B4 were better than textbook B3. And textbook code B3 was better than B1 for acid-base titration topic.

\section{The Development of Learning Module}

The development of chemistry learning module on teaching of acid-base titration have been conducted. There were four sub-chapters in this module. Type of innovation for first sub-chapter "basic concept of acid-base titration" was integration of media by giving figure about equipment in titration and e- media (website) about technique of titration. Type of innovation for second sub-chapter was giving questions and answer about indicator in titration and giving information in the corner about indicator. Types of innovation for third sub-chapter " calculation in acid-base titration" was giving sample problem, integration of outside activity to find vinegar in many concentration in market, integration of media by giving video in e- media about how to conduct acid- base titration, and integration of laboratory experiment. Types of innovation for fourth sub-chapter "types of acid-base titration and its curves" by integration of laboratory experiment doing titration between $\mathrm{HCl}$ solution with a standard $\mathrm{NaOH}$ solution.

\section{The Standarization of Innovative Learning Module}

The innovative chemistry learning module that have fully completed by researcher, then it was standarized by giving to the expert lecturer to make correction and to fill the questionnaire to give the standarization score.

TABLE I. THE QUESTIONNAIRE RESULT OF INNOVATIVE CHEMISTRY LEARNING MODULE STANDARIZATION BY CHEMISTRY LECTURERS, TEACHERS AND STUDENTS.

\begin{tabular}{|c|c|c|c|c|c|}
\hline \multirow{2}{*}{$\begin{array}{c}\text { The } \\
\text { Standard } \\
\text { Suitability }\end{array}$} & \multirow{2}{*}{ Description } & \multicolumn{3}{|c|}{ Point } & \multirow[b]{2}{*}{ Average } \\
\hline & & $\mathrm{L}$ & $\mathrm{T}$ & S & \\
\hline \multirow[t]{2}{*}{ Content } & $\begin{array}{l}\text { The completeness of } \\
\text { contents }\end{array}$ & 3.50 & 3.67 & 3.50 & 3.56 \\
\hline & The accurate of content & 3.50 & 4.00 & 3.45 & 3.65 \\
\hline \multirow{2}{*}{ Extension } & $\begin{array}{l}\text { Presented the extention of } \\
\text { material }\end{array}$ & 4.00 & 4.00 & 3.55 & 3.85 \\
\hline & $\begin{array}{l}\text { Clear the derived of } \\
\text { material }\end{array}$ & 4.00 & 4.00 & 3.30 & 3.77 \\
\hline \multirow[t]{2}{*}{ Depth } & $\begin{array}{l}\text { The material presented } \\
\text { start from introduction of } \\
\text { concepts to interaction } \\
\text { with concepts }\end{array}$ & 4.00 & 4.00 & 3.60 & 3.87 \\
\hline & $\begin{array}{l}\text { Application concepts } \\
\text { with example }\end{array}$ & 3.50 & 4.00 & 3.65 & 3.72 \\
\hline \multirow{3}{*}{ Design } & $\begin{array}{l}\text { The suitable between } \\
\text { design layout with } \\
\text { material }\end{array}$ & 2.00 & 4.00 & 3.85 & 3.28 \\
\hline & $\begin{array}{l}\text { Presentation of table and } \\
\text { images }\end{array}$ & 3.50 & 3.67 & 3.70 & 3.62 \\
\hline & $\begin{array}{l}\text { Involving learners } \\
\text { (interactive) }\end{array}$ & 4.00 & 4.00 & 3.60 & 3.87 \\
\hline \multirow{3}{*}{ Languange } & $\begin{array}{l}\text { In accordance with } \\
\text { development of learner }\end{array}$ & 3.50 & 4.00 & 3.65 & 3.72 \\
\hline & Communicative & 3.50 & 3.67 & 3.60 & 3.59 \\
\hline & $\begin{array}{l}\text { Straight forward (the } \\
\text { accuracy of use the term } \\
\text { language and symbol) }\end{array}$ & 4.00 & 4.00 & 3.60 & 3.87 \\
\hline & Average & 3.58 & 3.92 & 3.59 & 3.70 \\
\hline
\end{tabular}

There were 2 expert lecturers from department of chemistry in FMIPA UNIMED that standarized the module. The criteria that is in questionnaire's content were content, extention, depth, design, and language where each criteria is developed to another aspect that made the judge easy to evaluate, easy to make some correction and easy to revise again.

After that researcher revised the module and make some correction. Then, the innovative chemistry learning module was standarized again to chemistry teacher in MAN 2 Model Medan, MAN 1 Medan, and SMAN 5 Binjai. The researcher was also standarized the module to 20 students in MAN 2 Model Medan Grade XI IPA. So, the total of standarizators were 25 people.

Based on the overall result obtained that the average of the lecturer was 3.58, the teacher was 3.92, and students was 3.59 . the total average is 3.70 . It categorized as valid and the innovative learning module is not needed to revise anymore. It means that the innovative learning module has successfully developed, obtained the standard innovative learning module, and reasonable as media that using by students.

\section{CONCLUSION}

Based on the result of research that obtained from the result of data analysis, it can be concluded that the respondent's perception of bilingual chemistry textbook shown that textbook code B3 $(75 \%)$ were better than B2 (55\%), Code B4 (50\%) and Code B3 (35\%). Moreover, the standard innovative learning module that developed by researcher got the positive response from the chemistry lecturers, teachers and students with point that given is 3.70 . To sum up, the development of chemistry learning module to be an innovative learning module could be used as a learning media on teaching of acid-base titration for senior high school students.

\section{ACKNOWLEDGMENT}

The author would like to acknowledge Prof. Manihar Situmorang, M.Sc., Ph.D. for supervising the research. Also, author's gratitude is addressed to the Headmaster of MAN 1, MAN 2 and SMAN 5 Binjai.

\section{REFERENCES}

[1] N. I. Simatupang, and M. Situmorang, "Innovation of Senior High School Chemistry Textbook to Improve Students Achievement in Chemistry," The $2^{\text {nd }}$ Intl. Con. Indonesian Chem. Soc. in Chemistry, pp. 44-42, October, $22-23^{\text {th }} 2013$.

[2] M. Situmorang, B. Simarmare, J. Elnovrey, P. D. Naiborhu, and D. Sumbayak, "The Development of Chemistry Learning Module for RSBI Senior High School Students," Research Report of Teaching Grant KBI FMIPA UNIMED, Medan, 2012.

[3] M. Situmorang, M. Sinaga, D. A. B. Tarigan, C. J. Sitorus, and A. M. L. Tobing, "The Effectivity of Innovated Chemistry Learning Methods to Increase Student's Achievement in Teaching of Solubility and 
Solubility Product," Jurnal Penelitian Bidang Pendidikan, vol. 17(1), pp. 29-31, 2011.

[4] M. Situmorang, "Pengembangan Buku Ajar Kimia SMA Melalui Invasi Pembelajaran dan Integrasi Pendidikan Karakter untuk Meningkatkan Hasil Belajar Siswa," Prosiding Seminar dan Rapat Tahunan BKS PTN-B Bidang MIPA di Bandar Lampung, pp. 237-246, May $10^{\text {th }}-12^{\text {th }}$ 2013.

[5] M. Yusfiani, and M. Situmorang, "Pengembangan dan Standarisasi Buku Ajar Kimia SMA/MA Kelas XII Semester I Berdasarkan Standar Isi KTSP,” Jurnal Penelitian Bidang Pendidikan, vol. 17(1), pp. 39-40, 2011.

[6] H. G. Parulian, and M. Situmorang, "Inovasi Pembelajaran di Dalam Buku Ajar Kimia SMA untuk Meningkatkan Hasil Belajar Siswa Kelas XI,” Jurnal Penelitian Bidang Pendidikan, vol. 19(2), pp. 74-76, 2013. 